\title{
Benefit-Risk Assessment for Angiotensin System Modulators among Severe Acute Respiratory Syndrome Coronavirus 2 (SARS-CoV-2) Patients
}

Maxine Gossell-Williams*

Associate Professor, Pharmacology and Pharmacy Section, Faculty of Medical Sciences, University of the West Indies, Mona, Kingston, Jamaica

DOI: $10.36347 /$ sajp.2020.v09i07.006

| Received: 09.07.2020 | Accepted: 23.07.2020 | Published: 26.07.2020

*Corresponding author: Maxine Gossell-Williams

Short Communication

Copyright @ 2020: This is an open-access article distributed under the terms of the Creative Commons Attribution license which permits unrestricted use, distribution, and reproduction in any medium for non-commercial use (NonCommercial, or CC-BY-NC) provided the original author and source are credited.

\section{INTRODUCTION}

Recent commentary posits that increased occurrence of death from the 2019 Severe Acute Respiratory Syndrome Coronavirus 2 (SARS-CoV-2) in patients with hypertension and diabetes mellitus could be related to the drugs that modulate the angiotensin system, with the suggestions that these drugs should be withdrawn during SARS-CoV-2 management [1]. There is however strong opposition to this position [2] and has triggered professional bodies to issue warnings.

The two main enzymes in the angiotensin system are angiotensin-converting enzyme (ACE) and ACE2 found in epithelial cell lining the lungs and both modulate the physiological processes that occur with lung injury. The depletion of ACE2 was described in the pathology of the 2002-2003 severe acute respiratory syndrome coronavirus (SARS-CoV) [3-5]. With the rapidly emerging data suggesting insult to the respiratory tract induced by SARS-CoV-2 is also related to depletion of ACE2 [5], the possible changes in benefit versus risk profile of ACE inhibitors (ACEi) and angiotensin receptor blockers (ARB) in infected patients requires attention.

The protection of the lungs with decrease availability of ACE and blockade of angiotensin II type 1a receptors was observed in studies involving human and murine cell lines and in vivo murine models [3, 6]. This possible advantage of angiotensin system modulation is consistent with data from clinical studies. The protective effects of ACEi in the risk of pneumonia was reported in a systematic review and meta-analysis of 37 studies conducted in Asian countries, Europe and the United States of America. The review did not detect any differences in patients on ARB [7]. The possible relationship of microorganisms involved with the pathological outcomes was however not assessed. In a study of 13,832 Taiwanese patients with a history of stoke, hospitalized with non-viral related pneumonia, the protective effect of ACEi was also reported and the benefit was shown to be dose related; no benefits were reported for ARB [8]. Similar findings were also reported in a retrospective review of patients hospitalized at a tertiary care centre in the United States of America with viral related acute respiratory illness. The viruses identified in the 1055 patients included in the study were rhinovirus/ enterovirus, influenza A and respiratory syncytial virus. Patient who were on ACEi prior to hospital admission and continued on ACEi therapy during hospitalization were found to be at lower risk of morbidity/mortality than patients not on ACEi. Furthermore, the researchers identified loss of this protective benefit with discontinuation of ACEi on hospital admission. No differences were found with ARB [9].

The suggestion that ACEi and ARB should be contraindicated in patients infected with SARS-CoV-2 is based on the possible overexpression of ACE2, placing these patients at a greater risk of the lung injury from the coronavirus infection. Although evidence exist of ACEi and ARBs inducing overexpression of ACE2 in animal studies [10], there is no clinical study to support ACE2 overexpression promoting insult to the lungs. ACEi and ARB have proven efficacy in the therapy of patients for whom they are prescribed and the current published data suggest that there may be additional benefits from pathogen induced lung injury. SARS-CoV-2 infection cases will most likely continue to include a large proportion of patients on angiotensin system modulators; therefore active safety monitoring strategies are needed to ensure these drugs are providing more benefits than risks. 
Conflict of Interest: Nothing to declare

\section{REFERENCES}

1. Fang L, Karakiulakis G, Roth M. Are patients with hypertension and diabetes mellitus at increased risk for COVID-19 infection? The Lancet Respiratory Medicine. 2020; 8(4): e21.

2. FitzGerald GA. Misguided drug advice for COVID-19. Science. 2020; 67(6485):1434.

3. Kuba K, Imai Y, Ohto-Nakanishi T, Penninger JM. Trilogy of ACE2: A peptidase in the reninangiotensin system, a SARS receptor, and a partner for amino acid transporters. Pharmacology \& Therapeutics. 2010;128(1):119-28.

4. Jia HP, Look DC, Shi L, Hickey M, Pewe L, Netland J, Farzan M, Wohlford-Lenane C, Perlman S, McCray PB. ACE2 receptor expression and severe acute respiratory syndrome coronavirus infection depend on differentiation of human airway epithelia. Journal of virology. 2005 Dec 15;79(23):14614-21.

5. Wan Y, Shang J, Graham R, Baric RS, Li F. Receptor Recognition by the Novel Coronavirus from Wuhan: an Analysis Based on Decade-Long Structural Studies of SARS Coronavirus. J Virol. 2020; 94(7):e00127-20.
6. Imai Y, Kuba K, Rao S, Huan Y, Guo F, Guan B, Yang P, Sarao R, Wada T, Leong-Poi H, Crackower MA. Angiotensin-converting enzyme 2 protects from severe acute lung failure. Nature. 2005 Jul;436(7047):112-6.

7. Caldeira D, Alarcão J, Vaz-Carneiro A, Costa J. Risk of pneumonia associated with use of angiotensin converting enzyme inhibitors and angiotensin receptor blockers: systematic review and meta-analysis. BMJ. 2012;345:e4260.

8. Liu CL, Shau WY, Wu CS, Lai MS. Angiotensinconverting enzyme inhibitor/angiotensin II receptor blockers and pneumonia risk among stroke patients. Journal of Hypertension. 2012; 30(11):2223-9.

9. Henry C, Zaizafoun M, Stock E, Ghamande S, Arroliga AC, White HD, editors. Impact of angiotensin-converting enzyme inhibitors and statins on viral pneumonia. Baylor University Medical Center Proceedings. 2018; 31(4):419-423.

10. Ferrario CM, Jessup J, Chappell MC, Averill DB, Brosnihan KB, Tallant EA, Diz DI, Gallagher PE. Effect of angiotensin-converting enzyme inhibition and angiotensin II receptor blockers on cardiac angiotensin-converting enzyme 2 . Circulation. 2005 May 24;111(20):2605-10. 